\title{
PEMBATALAN AKTA HIBAH OLEH AHLI WARIS SETELAH PUTUSAN PENGADILAN AGAMA
}

\author{
Muhammad Fikri Syuhada \\ Program Studi Magister Kenotariatan PPS Unisma \\ Jalan Mayjen Haryono Nomor 193 Malang \\ Email:m.fikrisyuhada@gmail.com
}

\begin{abstract}
Abstrak
Permasalahan yang diteliti tentang pembatalan akta hibah oleh ahli waris dan tinjauan hukum Islam dalam pembatalan akta hibah oleh ahli waris setelah putusan Pengadialan Agama. Ahli waris dapat mengajukan suatu pembatalan hibah melalui permohonan pembatalan di Pengadilan Agama dan dengan adanya putusan pembatalan hibah yang telah memiliki kekuatan hukum tetap, maka berakibat hukum dengan segala macam barang yang telah dihibahkan dikembalikan kepada si penghibah atau ahli warisnya. Kompilasi hukum Islam memberikan batasan dalam pemberian hibah hanya 1/3 dari harta warisan dengan pertimbangan kemaslahatan bagi ahli waris. Menurut Kompilasi Hukum Islam bahwa hibah dalam perkara ini tidak sah dan dapat dilakukan penarikan atau pencabutan kembali. Karena tidak terpenuhinya salah satu persyaratan dalam syarat-syarat Pemberian hibah menurut hukum Islam.
\end{abstract}

Kata kunci : hukum Islam, pembatalan akta, hibah, Notaris, ahli waris

\section{Abstract}

Problems examined regarding the cancellation of the grant by the heirs and Islamic law review in the cancellation of the grant by the heirs after the decision of the Religious Funding. The heirs may file a cancellation of the grant through a cancellation request in the Religious Court and with the verdict of the cancellation of the grant which has a permanent legal force, the legal consequence of all the goods that has been granted is returned to the entertainer or his heirs. The compilation of Islamic law limits the granting of only one-third of the inheritance property to the benefit of beneficiaries. According to Islamic Law Compilations that the grant in this case is illegal and can be withdrawn or revoked. Because it does not meet one of the requirements in the terms of Grants grant under Islamic law.

Keywords: Islamic law, cancellation of deed, grant, Notary, heir 


\section{PENDAHULUAN}

Islam mengajarkan kepada manusia untuk saling tolong menolong baik ke sesama muslim ataupun non muslim. Salah satu bentuk tolong menolong dalam Islam adalah pemberian suatu benda secara sukarela dan tanpa mengharap imbalan dari seseorang yang disebut dengan Hibah. Hibah dalam hukum Islam bertujuan untuk mempererat silaturahmi diantara manusia dan kedekatan kepada Tuhan karena sifat hibah berkaitan erat juga dengan hubungan kepada Allah sebagai bukti kecintaan sesama makhluk ciptaannya. Hibah di negara Indonesia ini diatur dalam beberapa sistem hukum, yaitu diatur dalam hukum Perdata, hukum adat dan hukum Islam.

Dalam KUH Perdata, hibah disebut Schenking yang berarti suatu persetujuan dengan si pemberi hibah di waktu hidupnya dengan cuma-cuma dan dengan tidak ditarik kembali, menyerahkan sesuatu benda guna keperluan si penerima hibah untuk digunakan sebagai layaknya milik pribadi. Dalam KUH Perdata, sama sekali tidak mengakui lain-lain hibah, kecuali hibah di antara orang-orang yang masih hidup.

Dalam hukum, hibah yang telah diberikan tidak dapat ditarik kembali. Undang-undang telah menetapkan aturan mengenai hibah dalam pasal 1666 KUHPerdata yang berbunyi, bahwa penghibahan adalah suatu persetujuan dengan mana seorang penghibah menyerahkan suatu barang secara cuma-cuma, tanpa dapat menariknya kembali, untuk kepentingan seseorang yang menerima penyerahan barang itu. Undang-undang hanya mengakui penghibahan-penghibahan antara orang-orang yang masih hidup.

Dalam hukum adat, yang dimaksud dengan hibah adalah harta kekayaan seseorang yang dibagi-bagikannya diantara anak-anaknya pada waktu ia masih hidup. Penghibahan tersebut dilakukan untuk menghindari terjadinya percekcokan diantara anak-anaknya yang akan terjadi apabila ia telah meninggal dunia.

Kompilasi Hukum Islam Pasal 171 huruf (g) menjelaskan, hibah adalah pemberian suatu benda secara sukarela dan tanpa imbalan dari seseorang kepada orang lain yang masih hidup untuk dimiliki. Pada dasarnya, mengenai batasan harta yang dihibahkan tidak terbatas jumlahnya tergantung kepada kehendak dan keinginan pemberi hibah. Sedangkan dalam KHI Pasal 210 ayat (1) menyebutkan bahwa orang yang telah berumur sekurang-kurangnya 21 tahun, berakal sehat dan tanpa ada paksaan dapat menghibahkan sebanyak-banyaknya $1 / 3$ dari harta bendanya kepada orang lain atau lembaga dihadapan dua orang saksi untuk dimiliki.

Berdasarkan Pasal 212 KHI bahwa hibah tidak dapat ditarik kembali, kecuali hibah orang tua kepada anak kandung. Hibah dari orangtua

${ }^{1}$ Abdul Manan, Aneka Masalah Hukum Perdata Islam Di Indonesia, Jakarta : Kencana,2006, hal. 131. 
kepada anak kandung, hibah tersebut dapat ditarik kembali atau dibatalkan. Sementara yang menjadi objek dari hibah adalah harta warisan. Hubungan hibah dengan waris berdasarkan Pasal 211 KHI hibah dari orang tua kepada anak kandung dapat diperhitungkan sebagai warisan. Pemberian hibah ini dilakukan sewaktu pemberi hibah masih hidup. Hibah sebagai salah satu jalan keluar pembagian harta peninggalan untuk menghindari dari konflik yang terjadi dikebanyakan pembagian warisan dikarenakan faktor kelalaian manusia itu sendiri.

Dalam sebuah putusan Pengadilan Agama Kota Kediri Nomor : 324/Pdt.G/2010/PA.Kdr, majlis hakim Pengadilan Agama Kota Kediri dalam pertimbangan hukumnya berpendapat bahwa penghibahan yang dilakukan almarhum Anas Rauf bin Jamrin kepada anak angkatnya Atik Winarti binti jamingan adalah tidak sah, dengan dasar pertimbangan Pasal 210 ayat (1) dan (2) Kompilasi Hukum Islam. Dalam hibah tersebut tidaklah sesuai dengan syarat sah hibah yang terdapat dalam Kompilasi Hukum Islam Pasal 210 ayat (1) dan (2), karena harta yang dihibahkan lebih dari 1/3 dari harta bendanya dan harta tersebut bukanlah sepenuhnya milik penghibah Anas Rauf bin Jamirin. Sehingga dalam putusan ini terdapat putusan yang menyatakan pembatan hibah.

Melihat dari ketentuan Pasal 1666 KUHPerdata dan Pasal 212 KHI yang menyatakan bahwa hibah tidak dapat ditarik kembali, maka terdapat pertentangan antara ketentuan peraturan Pasal 1666 KUHPerdata dan Pasal 212 KHI dengan Putusan Pengadilan Agama Nomor : 324/Pdt.G/2010/PA.Kdr.

Berdasarkan uraian tersebut maka timbul permasalahan mengenai bagaimanakah pembatalan akta hibah oleh ahli waris yang dibuat oleh Notaris; dan bagaimanakah Tinjauan Hukum Islam dalam pembatalan akta hibah oleh ahli waris setelah Putusan Pengadilan Agama.

\section{METODE PENELITIAN}

Jenis penelitian yang dipergunakan dalam penelitian ini adalah deskriptif, yaitu jenis penelitian yang sifatnya mendeskripsikan atau menjelaskan peraturan-peraturan yang ada dan saat ini berlaku sebagai hukum positif. Sebagai konsekuensi pemilihan topik permasalahan yang akan dikaji dalam penelitian yang objeknya adalah permasalahan hukum, maka penelitian ini merupakan penelitian hukum normatif. ${ }^{2}$

Pendekatan peraturan perundang-undangan (statue aproach). Selain pendekatan perundang-undangan penelitian ini juga menggunakan pendekatan konseptual (conceptual approach). Pengumpulan bahan

${ }^{2}$ Suratman, dan Philips Dillah, Metode Penelitain Hukum, (Bandung: Alfabeta, 2015), hal: 51. 
hukum, baik pengumpulan bahan hukum primer, bahan hukum sekunder, maupun bahan hukum tersier, peneliti melakukannya dengan cara mempelajari dan mencatat bahan-bahan hukum yang diperlukan. Analisis bahan hukum dalam penelitian ini peneliti menggunakan cara deskriptif analisis

\section{PEMBAHASAN}

\section{Pembatalan Akta Hibah yang dibuat Notaris oleh Ahli Waris}

Dasar hukum hibah dalam Hukum Islam telah diatur dalam AlQur'an dan Hadits yang menerangkan bahwa hibah adalah pemberian seseorang kepada orang lain. Berdasarkan Kompilasi Hukum Islam dalam pasal 171 diartikan bahwa hibah adalah pemberian suatu benda secara sukarela dan tanpa imbalan dari sesorang kepada orang lain yang masih hidup untuk dimilikinya.

Pengertian hibah dalam hukum perdata telah dituangkan dalam KUHPerdata Pasal 1666 yang menyebutkan bahwa hibah adalah suatu perjanjian dengann mana si penghibah pada waktu hidupnya dengan cumacuma dan dengan tidak dapat ditarik kembali, menyerahkan suatu benda guna keperluan penerima hibah yang menerima penyerahan itu. Sedangkan berdasarkan Pasal 1667 KUHPerdata hibah hanyalah dapat berupa bendabenda yang sudah ada. Jika hibah itu meliputi benda-benda yang akan ada dikemudian hari, maka sekedar mengenai itu hibahnya adalah batal.

Pada dasarnya menurut Pasal 1676 KUHPerdata semua orang boleh memberikan dan menerima hibah, kecuali yang oleh undang-undang dinyatakan tidak mampu untuk itu. Berdasarkan KUHPerdata proses penghibahan harus melalui akta Notaris ${ }^{3}$ yang aslinya disimpan oleh Notaris yang bersangkutan. Hiibah apabila dalam hari penghibahan itu dinyatakan dengan kata-kata yang tegas dan diterima oleh penerima hibah atau dengan suatu akta otentik telah diberikan kuasa kepada orang lain maka hibah tersebut mengikat dan mempunyai akibat hukum.

Hibah digolongkan pada perjanjian sepihak yang ditanggungkan kepada pemberi hibah. Namun dalam KUHPerdata terdapat ketentuan terhadap perjanjian hibah, yang mana penerima hibah juga dapat dikenakan kewajiban dalam hibah yang diberikan kepadanya, yaitu :

a. Hak yang timbul dari peristiwa hibah.

1) Dalam Pasal 1671 KUHPerdata disebutkan bahwa pemberi hibah berhak untuk memakai sejumlah uang dari harta atau benda yang

\footnotetext{
${ }^{3}$ Abdul Wahid, Sunardi, Mariyadi, Penegakan Kode Etik Profesi Notaris, (Jakarta:
} Nirmana Media, 2017), hal. 35. 
dihibahkannya, asalkan hak ini telah diperjanjikan dalam penghibahan.

2) Dalam Pasal 1672 KUHPerdata disebutkan bahwa pemberi hibah berhak untuk mengambil benda yang telah diberikannya jika si penerima hibah meninggal terlebih dahulu dari si penghibah, dengan catatan hal tersebut berlaku apabila telah diperjanjikan sebelumnya.

3) Pemberi hibah dapat menarik kembali pemberiannya, jika penerima hibah tidak memenuhi kewajibah yang telah ditentukan dalam akta hibah atau hal-hal lain yang dinyatakan dalam KUHPerdata.

b. Kewajiban yang timbul dari peristiwa hibah

1) Kewajiban pemberi hibah

Setelah pemberi hibah menyerahkan harta atau benda yang dihibahkannya kepada si penerima hibah, maka semenjak itu tidak ada kewajiban-kewajiban yang mengikat pemberi hibah

2) Kewajiban penerima hibah

KUHPerdata memberikan kemungkinan bagi penerima hibah untuk melakukan suatu kewajiban kepada penerima hibah sebagai berikut:

a) penerima hibah berkewajiban untuk melunasi hutang-hutang penghibah atau benda-benda lain, dengan catatan hutang dan beban yang harus dibayar telah disebutkan secara tegas dalam akta hibah.

b) penerima hibah diwajibkan untuk memberikan tunjangan nafkah kepada pemberi hibah apabila pemberi hibah jatuh miskin.

c) penerima hibah diwajibkan untuk mengembalikan benda yang telah dihibahkan berdasarkan aturan-aturan yang telah diatur dalam KUHPerdata.

Pada hakikatnya hukum merupakan perlindungan bagi kepentingan manusia, yang berbentuk kaidah dan norma. Hubungan hukum yang muncul antara pemberi hibah dan penerima hibah merupakan hubungan hukum karena adanya perjanjian antara pemberi hibah selaku debitur dan penerima 
hibah selaku kreditur. ${ }^{4}$ Dalam pembatalan hibah, dapat diartikan bahwasannya hibah adalah hubungan hukum yang sepihak, artinya pemberi hibah memberikan hibah kepada penerima hibah secara sukarela tanpa meminta imbalan. Hal ini merupakan pemberi hibah hanya memiliki kewajiban saja tanpa mempunyai hak. Berdasarkan KUHPerdata tidak dijelaskan bahwasannya hibah yang telah diberikan tidak dapat ditarik kembali. Namun pemberi hibah dapat mengajukan gugatan pembatalan hibah apabila penerima hibah melakukan hal sebagaimana yang diatur dalam Pasal 1688 KUHPerdata.

Berdasarkan Pasal 1688 KUHPerdata yang menyatakan suatu penghibahan tidak dapat dicabut dan karena itu tidak dapat pula dibatalkan, kecuali dalam hal-hal berikut :

a. jika syarat-syarat penghibahan tidak dipenuhi oleh pemberi hibah;

b. jika orang yang diberi hibah bersalah dengan melakukan atau ikut melakukan suatu usaha pembunuhan atau kejahatan lain atas diri penghibah;

c. jika penghibah jatuh miskin sedang yang diberi hibah menolak untuk memberi nafkah kepadanya.

Dalam kehidupan bermasyarakat, terdapat suatu kebebasan untuk berkontrak, namun kebebasan tersebut mempunyai batasan agar tidak melanggar dasar-dasar kehidupan dalam bermasyarakat. Larangan atau pembatasan kebebasan tidak ada artinya apabila tidak terdapat sanksi didalamnya. Suatu instrumen yang ampuh yang digunakan untuk memaksakan ketentuan larangan dan pembatasan tersebut ialah pemberian akibat suatu "kebatalan". ${ }^{5}$ Ajaran kebatalan berlaku pada semua perbuatan hukum, dengan mengatakan suatu perbuatan hukum batal berarti karena adanya cacat hukum yang berakibat pada tujuan perbuatan hukum itu menjadi tidak berlaku.

Perbuatan hukum yang batal adalah perbuatan hukum yang walaupun mengandung unsur-unsur perbuatan hukum, namun karena alasan tertentu yang telah diatur dalam undang-undang diberi sanksi tidak mempunyai akibat hukum. Kebatalan diatur dalam Buku III, Bagian Kedelapan Bab IV KUHPerdata, namun bagian tersebut tidak mengatur kebatalan secara lengkap.

${ }^{4}$ Widya Anggaraeni, Tangung Gugat Pemberi Hibah Akibat Pembatalan Hibah, (Surabaya: Universitas Airlangga, 2006), hal. 52

${ }^{5}$ Herlien Budiono, Kumpulan Tulisan Hukum Perdata di Bidang Kenotariatan, (Bandung: Citra Aditya Bakti, 2012), hal. 364 
Dalam praktik pelaksanaan hibah di Pengadilan Agama, sering dijumpai kasus pelaksanaan hibah yang dilakukan oleh seseorang kepada anak angkatnya dengan penghibahan semua harta yang dimilikinya. ${ }^{6}$ Kasus tersebut telah diputus oleh Pengadilan Agama Kediri dengan perkara No.324/Pdt.G/2010/PA.Kdr. Untuk mengetahui ketentuan hukum terkait dengan pembatalan akta hibah yang dibuat oleh Notaris, maka penulis memberikan uraian kasus posisi gugatan pembatalan hibah di Pengadilan Agama Kediri dengan perkara No.324/Pdt.G/2010/PA.Kdr tertanggal 15 Agustus 2010 sebagai berikut :

Djuminah binti Marjuki, swasta, bertempat tinggal di Jl. KH. Agus Salim No.83 Kelurahan Bandar Kidul Rt.20 Rw.03 Kecamatan Mojoroto Kota Kediri (Penggugat) mengajukan gugatan terhadap Atik Winarti binti Jamingan (Tergugat)

Surat gugatan diajukan dengan dalil-dalil sebagai berikut :

1. Bahwa Penggugat dan almarhum suaminya (Anas Rauf bin Jamirin) semasa hidup dalam perkawinannya memiliki harta bersama berupa :

- Satu buah rumah permanen atas nama almarhum yang dibangun diatas tanah luas $964 \mathrm{~m}^{2}$ yang terletak di Jl. KH. Agus Salim No.83 Kelurahan Bandar Kidul Rt.20 Rw.03 Kecamatan Mojoroto Kota Kediri. (selanjutnya disebut objek sengketa)

2. Bahwa status Penggugat sewaktu menikah gadis sedangkan almarhum suami Penggugat (Anas Rauf bin Jamrin) duda dengan anak 1 (satu) orang bernama : Asnimar, Perempuan, umur 53 tahun dan selama perkawinan Penggugat dengan almarhum tidak memiliki anak tetapi memiliki anak angkat 3 (tiga) orang yaitu
a. Samsul Bahri, Laki-laki, umur 46 tahun;
b. Upik Tri Hartini, Perempuan, umur 39 tahun;
c. Atik Winarti, Perempuan, Umur 28 tahun.

3. Bahwa pada tahun 2007 almarhum suami Penggugat telah menghibahkan Objek sengketa tersebut kepada anak angkat yang ketiga bernama Atik Winarti (Tergugat), serta atas hibah tersebut sertifikat tanah (Objek sengketa) telah dipindah namakan atas nama Tergugat dan saat ini telah dikuasai oleh Tergugat

Alasan Penggugat mengajukan pembatalan hibah kepada Tergugat adalah :

${ }^{6}$ Abdul Manan, Op.Cit., hlm. 145 
1. Bahwa Penggugat sebagai istri sah dari almarhum suaminya baru menyadari bahwa $1 / 2$ dari objek sengketa tersebut adalah harta bersama yang merupakan hak milik Penggugat sehingga objek sengketa tersebut batal demi hukum karena objek sengketa tidak sepenuhnya milik Tergugat;

2. Bahwa pada dasarnya almarhum (Anas Rauf bin Jamirin) masih memiliki ahli waris yang lain yaitu anak bawaan almarhum suami Penggugat dan Penggugat, sehingga jika hibah diteruskan menghalangi ahli waris untuk menerima harta waris;

3. Bahwa oleh karena itu Penggugat mohon kepada Pengadilan Agama Kediri agar hibah almarhum suami Penggugat kepada Tergugat tersebut dibatalkan;

Berdasarkan keterangan dan dalil-dalil tersebut diatas, maka Penggugat memohon kepada Ketua Pengadilan Agama Kediri untuk memeriksa dan mengadili perkara ini dengan menjatuhkan putusan yang amarnya sebagai berikut :

1. Mengabulkan gugatan Penggugat;

2. Menetapkan hibah yang dilakukan oleh almarhum suami penggugat (Anas Rauf bin Jamirin) kepada Tergugat batal;

3. Menghukum kepada Tergugat untuk menyerahkan objek sengketa tersebut kepada Penggugat;

4. Menghukum Tergugat untuk membayar biaya perkara menurut hukum.

Dalam keterangannya saat dibacakan surat gugatan Penggugat yang isinya tetap dipertahankan oleh Penggugat dengan tambahan secara lisan yang pada pokoknya pada saat almarhum Anas Rauf bin Jamirin masih hidup pernah membatalkan hibah dengan caranya sendiri diluar prosedur hukum dengan cara merobek dan membakar surat hibah yang asli.

Tergugat telah mengajukan jawaban secara lisan yang pada pokoknya mengakui dan membenarkan seluruh dalil gugatan Penggugat dan tidak keberatan atas gugatan Penggugat untuk membatalkan hibah atas objek sengketa kepada Tergugat selama hal itu sesuai dengan prosedur hukum yang berlaku serta menyerahkan sepenuhnya kepada Majlis Hakim.

Berdasarkan hal-hal tersebut diatas, maka Pengadilan Agama Kediri menjatuhkan Putusan dengan Nomor : No.324/Pdt.G/2010/PA.Kdr tertanggal 15 Agustus 2010 yang menyatakan :

1. Mengabulkan gugatan Penggugat; 
2. Menetapkan batal hibah terhadap Satu buah rumah permanen atas nama almarhum yang dibangun diatas tanah luas $964 \mathrm{~m}^{2}$ yang terletak di Jl. KH. Agus Salim No.83 Kelurahan Bandar Kidul Rt.20 Rw.03, Kecamatan Mojoroto, Kota Kediri yang dilakukan oleh almarhum suami Penggugat kepada Tergugat;

3. Menghukum Tergugat atau siapa saja yang menguasai objek sengketa tersebut untuk menyerahkan kepada Penggugat;

4. Menghukum kepada Tergugat untuk membayar biaya perkara ini sebesar Rp 666.000,- (enam ratus enam puluh enam ribu rupiah).

Dalam hal ini atas nama Atik Winarti selaku Tergugat menerima putusan tersebut dan tidak mengajukan upaya hukum banding.

Para pihak yang dapat mengajukan suatu pembatalan hibah adalah pemberi hibah, ahli waris. Seorang istri dapat mengajukan suatu pembatalan hibah yang dilakukan oleh suaminya karena apabila hibah tersebut diteruskan akan menghalangi ahli waris untuk menerima harta waris. Sehingga untuk mengatasi hal tersebut maka seorang istri dari pemberi hibah yang telah meninggal dunia dapat mengajukan pembatalan hibah dengan alasan tersebut. Pemberi hibah pada dasarnya dapat melakukan permohonan pembatalan hibah apabila tidak tercapainya maksud dan tujuan sebagaimana yang diinginkan atau setelah pelaksanaan hibah tersebut, karena ahli waris merasa dirugikan maka ahli waris berhak untuk mengajukan gugatan pembatalan hibah berdasarkan prinsip legitieme portie berdasarkan putusan Mahkamah Agung No.990.K/Sip/1974, tanggal 6 April 1976. Untuk memenuhi hak dari para pihak yang akan membatalkan hibah harus memperkarakan di pengadilan, dimana Pengadilan Agama adalah pengadilan yang berwenang untuk memeriksa dan mengadili sengketa pembatalan hibah.

Legitime portie adalah bagian mutlak atau hak-hak ahli waris yang sering disebut legitimaris. Legitime portie harus dihitung apabila salah satu atau beberapa ahli waris menuntut haknya.

Proses pembatalan hibah pada dasarnya sama dengan pengajuan gugatan dengan materi pokok pembatalan hibah. Pengajuan gugatan terjadi apabila terdapat suatu sengketa antara para pihak. Dalam penyusunan suatu gugatan ada beberapa hal yang perlu diperhatikan yaitu:

a. Tiap orang merasa diinginkan dapat mengajukan gugatan terhadap pihak yang dianggap merugikan lewat pengadilan

b. Gugatan dapat diajukan secara lisan atau tertulis dan bila perlu dapat minta bantuan kepada Ketua Pengadilan 
c. Gugatan itu harus diajukan oleh yang berkepentingan

d. Tuntutan hak di dalam gugatan harus merupakan tuntutan hak yang ada kepentingan hukumnya, yang dapat dikabulkan apabila kebenaran dapat dibuktikan dalam siding pemeriksaan

e. Mengenai persyaratan tentang isi daripada gugatan tidak ada ketentuan, tetapi ada pokok gugatan yang meliputi:

1) Identitas para pihak

2) Dalil-dalil konkret tentang adanya hubungan hukum yang merupakan dasar serta alasan-alasan daripada tuntutan. Dalildalil ini lebih dikenal dengan istilah fundamentum petendi.

3) Tuntutan atau petitum harus jelas dan tegas. ${ }^{7}$

Proses penyelesaian sengketa melalui lembaga peradilan (litigasi), akan ada putusan hakim mengenai perkara pembatalan hibah dengan memperhatikan hak dan kewajiban para pihak atas objek yang di sengketakan. Setelah ada putusan hakim terkait perkara tersebut, maka hakim akan menerbitkan hak dan menetapkan hubungan hukum baru antara pihak yang bersankutan dan akan menimbulkan akibat hukum terhadap harta hibah yang dimohonkan pembatalan hibah tersebut. Dengan adanya putusan Pengadilan yang berkekuatan hukum tetap, maka hibah menjadi batal demi hukum dan sebagai akibatnya objek sengketa yang telah diberikan dalam penghibahan kembali menjadi milik penghibah secara keseluruhan. Pada dasarnya, penyelesaian sengketa melalui jalur litigasi adalah untuk mencari keadilan dan agar diselesaikan secara damai menurut peraturan perundang-undangan yang berlaku.

Dalam penelitian ini penulis menggunakan teori kepastian hukum, yang mana kepastian memiliki arti ketentuan, ketetapan dan jika kata kepastian itu digabungkan dengan kata hukum menjadi kepastian hukum yang memiliki arti perangkat hukum suatu negara yang mampu menjamin hak dan kewajiban setiap warga negara. Dalam memahami nilai kepastian hukum yang harus diperhatikan adalah bahwa nilai itu mempunyai relasi yang erat dengan instrumen hukum yang positif dan peranan negara dalam mengaktualisasikannya dalam hukum positif. Bahkan peranan negara tidak saja sebatas pada tataran itu saja, negara pun mempunyai tanggung jawab untuk menjalankan dan menegakkannya. Kepastian hukum harus menjadi

${ }^{7}$ R. Soeroso, Praktik Hukum Acara Perdata Tata Cara dan Proses Persidangan, (Jakarta: Sinar Grafika, 1994), hal.26 
nilai bagi setiap pihak dalam setiap sendi kehidupan negara. ${ }^{8}$ Adapun landasan hukum dalam KHI mengenai hibah boleh dicabut sesuai dengan Pasal 212 KHI disebutkan bahwa hibah kepada anak dapat ditarik kembali.

Pemohonan pembatalan hibah terhadap harta hibah melalui pemohonan pembatalan di Pengadilan Agama dan dengan adanya putusan pembatalan hibah yang telah memiliki kekuatan hukum tetap, maka berakibat hukum dengan segala macam barang yang telah dihibahkan dikembalikan kepada si penghibah atau ahli warisnya. Pengembalian ini dilakukan dengan mengosongkan terlebih dahulu obyek hibah tersebut. Obyek hibah dalam kasus ini adalah sebuah rumah, maka penerima hibah yang telah menempati rumah tersebut harus meninggalkan rumah yang telah diterimanya tersebut sampai jangka waktu yang telah ditentukan berdasarkan putusan majelis hakim dalam pembatalan hibah. Apabila obyek hibah tersebut telah dibalik nama atau telah disertifikatkan atas nama penerima hibah, maka sertifikat dinyatakan tidak berlaku lagi. Pemberi hibah dapat mengajukan permohonan kepada Badan Pertanahan kembali dengan adanya pembatalan hibah tersebut dan sertifikat dapat dikembalikan lagi atas nama pemberi hibah atau ahli waris.

\section{Tinjauan Hukum Islam Dalam Pembatalan Akta Hibah Oleh Ahli Waris Setelah Putusan Pengadilan Agama}

Negara Indonesia merupakan negara hukum dimana hukum tertulis adalah sistem hukum nasional yang diakui di Indonesia. Untuk mengisi kekosongan hukum keluarga bagi Warga Negara Indonesia yang beragama Islam, diperlukan peraturan hukum Islam yang diatur dalam bentuk peraturan perundang-undangan di Indonesia.

Kumpulan dari peraturan hukum Islam tersebut dibukukan dalam bentuk Kompilasi Hukum Islam yang bertujuan untuk menghimpun bahanbahan hukum yang diperlukan sebagai pedoman dalam bidang hukum material para hakim di lingkungan Peradilan Agama. Bahan-bahan yang diangkat dari berbagai kitab yang bisa digunakan sebagai sumber pengambilan dalam penetapan hukum yang dilakukan oleh para hakim dan bahan-bahan yang berhubungan dengan itu. ${ }^{9}$

Berlakunya KHI tidak sama dengan berlakunya peraturan perundang-undangan. Hal ini dengan jelas dapat dilihat dari diktum kedua Keputusan Menteri Agama Nomor 154 Tahun 1991 tentang Pelaksanaan

\footnotetext{
${ }^{8}$ Sudarsono, Hukum Waris dan Sistem Bilateral, (Jakarta: Rineka Cipta, 1991),
} hal. 104.

9 Abdurrahman, Kompilasi Hukum Islam di Indonesia, (Jakarta: Akademika Presindo, 1992), hal. 14 
Instruksi Presiden Republik Indonesia Nomor 1 Tahun 1991, yakni dengan adanya frasa " sedapat mungkin". Meskipun demikian keadaannya, KHI mendorong terpenuhinya kebutuhan akan hukum Islam di Indonesia dalam sistem hukum Nasional. ${ }^{10}$

Ketentuan hibah dalam KHI telah diterima baik oleh para alim ulama Indonesia dalam Lokakarya yang dilaksanakan di Hotel Kartika Chandra Jakarta pada tanggal 2 sampai dengan 5 Februari 1988. Kemudian Kompilasi Hukum Islam ini diinstruksikan oleh Presiden Republik Indonesia dengan Inpres Nomor 1 Tahun 1991 kepada Menteri Agama RI untuk disebarluaskan sengketa perkawinan, hibah dan Shadaqah bagi umat Islam supaya berpedoman kepada Kompilasi Hukum Islam. Selanjutnya Menteri Agama RI mengeluarkan Keputusan Nomor 1 Tahun 1991 tentang penyebarluasan KHI kepada seluruh instansi pemerintaha dan masyarakat, baik melalui orientasi, penataran maupun dengan penyuluhan hukum. ${ }^{11}$

Dalam KHI, proses hibah, tertera di dalam Pasal210 sampai dengan 214. Yang pertama yaitu menjelaskan bahwa yang dapatmelakukan hibah adalah orang yang sekurang-kurangnya telah berumur 21 tahundan berakal sehat tanpa adanya paksaan dari orang lain untuk menghibahkansebanyakbanyaknya $1 / 3$ hartanya kepada orang lain atau lembaga dan harusdisaksikan oleh dua orang saksi, dan tidak lupa harta benda yang dihibahkan harusmerupakan hak milik dari si penghibah (wahab).

Dalam Agama Islam hibah dapat ditarik kembali sebagaimana yang telah tercantum dalam Pasal 212 KHI bahwa hibah tidak dapat ditarik kembali, kecuali hibah orang tua kepada anaknya. Tetapi orang tua tidak dapat menarik hibah tersebut secara sepihak, ada ketentuan berdasarkan hadist Rasullullah SAW yang diriwayatkan oleh Ibnu Umar dan Ibnu Abbas yang pada intinya adalah hibah dapat ditarik secara sepihak namun ketentuan ini tidak mudah apabila barang yang dihibahkan sudah berganti tangan.

Ulama Fiqh berpendapat apabila benda hibah masih dimiliki anak atau masih bergabung dengan orangtuanya dapat ditarik kembali, tetapi apabila sudah bercampur dengan harta miliknya, istrinya atau orang lain maka hibah tersebut tidak dapat ditarik kembali. Berdasarkan Hukum Islam perpindahan harta dari pemilik harta kepada ahli warisnya ada tiga macam yaitu yang pertama warisan, adalah berpindahnya harta ketika pewaris meninggal dunia. Kedua adalah wasiat memberikan harta atau memberikan sesuatu waktu hidup tapi diserahkan ketika pemberi meninggal dunia.

${ }^{10}$ Moh. Muhibbin dan Abdul Wahid, Hukum Kewarisan Islam, (Jakarta: Sinar Grafika, 2017), hal. 177.

${ }^{11}$ Abdul Manan, Op, Cit.,hlm. 145 
Ketiga adalah hibah diberikan kepada penerima hibah ketika pemberi masih hidup dan diserahkan ketika penerima hibah masih hidup juga.

Menurut KHI penyebab pertama suatu hibah dapat dibatalkan pada dasarnya adalah berdasarkan Hukum Islam, dimana seseorang dalam memberikan hibah atau banyaknya barang yang akan diberikan dibatasi oleh hukum sebanyak 1/3 dari harta kekayaan pemberi hibah. Tujuannya adalah untuk menghindari konflik atau pertengkaran yang terjadi antara sesama anggotakeluarga. Oleh karena itu apabila terjadi pemberi hibah kepada orang lain melebihi batas tersebut, maka keluarga pemberi hibah dapat mengajukan pembatalan terhadap hibah yang telah diberikan. Berdasarkan penjelasan tersebut, maka hibah dapat dibatalkan apabila penerima menelantarkan barang hibah. Kemudian penyebab kedua suatu hibah dapat dibatalkan adalah karena tidak sesuai dengan maksud dan tujuan dari pemberian hibah. Hibah hukumnya adalah Sunnah, karena ini merupakan suatu kebaikan.

Ketika seseorang yang menghibahkan seluruh hartanya kepada orang lain, agar hartanya bisa bermanfaat, karena si pemberi hibah takut hartanya akan jatuh ke tangan ahli waris yang tidak bisa bertanggung jawab dan hartanya akan sia-sia. Maka dari itu perlu adanya batasan untuk pemberian hibah karena dikhawatirkan akan hak-hak ahli waris yang tidak terpenuhi. Menurut Hukum Islam, hibah kepada yang sedianya berhak atas harta warisan pada waktu hidup pewaris tidak dipandang sebagai kewarisan, namun jika pemberian hibah orang tua kepada anaknya, padahal harta peninggalannya cukup banyak, ajaran Islam tentang wajib berbuat adil dalam memberikan hibah kepada anak lainnya harus diberikan juga hibah dari harta peninggalan. ${ }^{12}$

Apabila pewaris menghibahkan hartanya kepada bukan ahli waris, penghibaan dibatasi sepanjang tidak merugikan hak para ahli waris. Tetapi meskipun hibah terhadap selain ahli waris dibatasi sebanyak-banyaknya $1 / 3$, maka dari itu bukan berarti pemberi hibah seenaknya memberikan kepada anak-anaknya, karena dalam hal ini aspek keadilan yang harus sangat diperhatikan, Hibah dalam Hukum Islam mendapatkan perhatian khusus dan mempunyai persyaratan tertentu yang bertujuan untuk supaya hibah tetap dalam fungsinya. Penghibaan ini terjadi ketika anak-anak mulai berdiri sendiri, maupun oleh perkawinan atau oleh karena membentuk keluarga sendiri. Ahli waris juga dapat mengajukan pembatalan hibah disini dalam hal pemberian yang dilakukan pewaris melebihi batas maksimal yaitu 1/3. Tetapiterdapat pengecualian yaitu ahli waris semenda tidak dapat

${ }^{12}$ Ahmad Azhar Basyir, Hukum Waris Islam, (Yogyakarta: UII Press, 2004), hal. 149. 
mengajukan pembatalan hibah karena hubungan antara pewaris dengan semenda tidak termasuk kekerabatan dekat.

Dalam KHI menyatakan bahwa hibah dikatakan sah apabila memenuhi syarat-syarat hibah. Salah satupersyaratan hibah yaitu syaratsyarat pemberi hibah. Syarat-syaratpemberi hibah antara lain;

a. Dewasa, baliq dan berakal sehat

b. Pemberi adalah pemilik sah benda yang dihibahkan.

c. Pemberi tidak sedang dalam pengawasan orang lain ataumengalami perkara karena suatu sebab.

d. Tidak tertekan oleh beberapa pihak.

Berdasarkan point tersebut apabila dikaitkan dengan perkara dalam Putusan Pengadilan Agama Nomor: 324/Pdt.G/2010/PA.Kdr, dapat diketahui bahwa point 1,3 , dan 4 sudah dipenuhi persyaratannya oleh pemberi hibah. Namun pada point 2 yang menyatakan bahwa pemberi adalah pemilik sah benda yang dihibahkan, pada kasus penelitian ini benda yang dihibahkan oleh penghibah merupakan harta bersama dengan istri penghibah yang mana dalam pmberian hibah kepada penerima hibah, penghibah belum mendapatkan persetujuan dari istri penghibah. Sehingga benda tersebut bukan sepenuhnya hak milik pemberi hibah melainkan harta bersama yang apabila akan menghibahkan benda tersebut harus dengan kesepakatan dari istri penghibah. Berdasarkan persyaratan untuk syaratsyarat pemberi hibah makasalah satu persyaratan tersebut tidak dipenuhi sehingga hibah dalam kasus ini tidak saah menurut ajaran Islam.

Terkait permasalahan dalam Putusan Pengadilan Agama Nomor : 324/Pdt.G/2010/PA.Kdr, adalah benar berdasarkan Hukum Islam menganggap kekayaan suami dan istri masing-masing terpisah satu dengan lainnya, harta benda milik masing-masing, demikian juga dengan barangbarang yang diperoleh selama perkawinan berlangsung tidak dicampur melainkan terpisah satu sama lainnya, jadi artinya atas harta benda milik suami, istri tidak berhak untuk hak dan sebaliknya. Konsekueninya adalah menurut hukum Islam status harta benda seorang perempuan tidak berubah dengan adanya perkawinan. ${ }^{13}$ Apabila suami atau istri ingin menghibahkan hartanya terlepas dari kekuasaan orang lain termasuk suami atau istri yang menghibahkan hartanya berdasarkan Pasal 87 ayat (1) dan (2) Kompilasi Hukum Islam. Tetapi jika harta benda yang dihibahkan adalah merupakan harta bersama yang didapat setelah perkawinan maka jika salah satu ingin menghibahkan harta tersebut harus mendapat persetujuan pasangannya, hal

${ }^{13}$ MR Martiman Prodjihanimidjojo, Hukum Perkawinan Indonesia, (Jakarta: Indonesia Legal Center Publishing, 2002), hlm.36. 
tersebut berdasarkan Pasal 35 ayat 1 jo Pasal 36 ayat 1 Undang-undang Nomor 1 Tahun 1974 tentang Perkawinan. ${ }^{14}$ Tetapi jika salahsatu pihak meninggal dunia maka jika ingin melakukan hibah maka harus berdasarkan persetujuan ahli waris yaitu anak-anaknya.

Menurut Pasal $210 \mathrm{KHI}$, yaitu pemberi hibah dapat menghibahkan sebanyak-banyak $1 / 3$ harta bendanya kepada orang lain atau lembaga dihadapan dua orang saksi. Jadi pemberi hibah hanya dapat memberikan $1 / 3$ hartanya tapi dengan tetap memperhatikan ketentuan yang telah diatur, prinsip keadilan adalah hal utama yang diperlukan. Maka disini mafsadahnya lebih besar dari pada maslahatnya. Karena hibah yang diberikan lebih dari $1 / 3$ dari hartanya dan harta tersebut bukan sepenuhnya milik almarhum Anas Rauf. Perbuatan hukum dalam bentuk hibah perlu adanya pertimbangan sesuai aturan hukum. Untuk menghindari terjadinya pertengkaran antar keluarga, hibah dibagi sama rata berdasarkan ajaran Rasulullah SAW terhadap sahabatnya untuk berbuat adil terhadap anakanaknya.

Berdasarkan kasus tersebut almarhum memberikan seluruh hartanya kepada anak angkatnya, sedangkan anak angkat dan orang tua angkat tidak saling mewarisi karena tidak memiliki hubungan kekerabatan sebagaimana diatur dalam Pasal 209 ayat (1) KHI bahwa harta peninggalan anak angkat dibagi berdasarkan Pasal-pasal 176 sampai dengan 193 KHI, tetapi pada Pasal 209 ayat (2) KHI bahwa terhadap anak angkat yang tidak menerima wasiat wajibah sebanyak-banyaknya $1 / 3$ dari harta warisan orang tua angkatnya. Berkaitan dengan masalah di atas, Pasal 211 KHI telah memberikan solusi, yaitu dengan cara hibah yang diberikan orang tua kepada anaknya dapat diperhitungkan sebagai warisan. Pengertian "dapat " dalam Pasal tersebut bukan berartai imperatif (harus), tetapi merupakan salah satu alternatif yang dapat ditempuh untuk menyelesaikan perselisihan atau sengketa warisan. Sepanjang para ahli waris tidak ada yang mempersoalkan hibah yang sudah diterima oleh sebagian ahli waris, maka harta warisan yang belum dihibahkan dapat dibagikan kepada semua ahli waris sesuai dengan bagiannya masing-masing. Tetapi apabila ada sebagian ahli waris yang mempersoalkan hibah yang diberikan kepada sebagian ahli waris lainnya, maka hibah tersebut dapat diperhitungkan sebagai harta warisan, dengan cara memperhitungkan hibah yang sudah diterima dengan bagian warisan yang seharusnya diterima. Apabila hibah yang sudah diterima masih kurang dari bagian warisan maka tinggal menambah kekurangannya, dan sebaliknya apabila hibah tersebut melebihi dari bagian warisan maka kelebihan hibah tersebut dapat ditarik kembali untuk

${ }^{14}$ Ibid, hlm.38 
diserahkan kepada ahli waris yang kekurangan dari bagiannya. ${ }^{15}$ Dalam perkara ini tidak sah dan dapat dilakukan penarikan atau pencabutan kembali. Karena tidak terpenuhinya salah satu persyaratan dalam syaratsyarat pemberian hibah menurut hukum Islam.

\section{KESIMPULAN}

Pembatalan akta hibah yang dibuat Notaris oleh ahli waris, ahli waris dapat mengajukan suatu pembatalan hibah yang dilakukan oleh suaminya karena apabila hibah tersebut diteruskan akan menghalangi ahli waris untuk menerima harta waris. Sehingga untuk mengatasi hal tersebut maka seorang istri dari pemberi hibah yang telah meninggal dunia dapat mengajukan pembatalan hibah dengan alasan tersebut. Pemohonan pembatalan hibah terhadap harta hibah melalui pemohonan pembatalan di Pengadilan Agama dan dengan adanya putusan pembatalan hibah yang telah memiliki kekuatan hukum tetap, maka berakibat hukum dengan segala macam barang yang telah dihibahkan dikembalikan kepada si penghibah atau ahli warisnya. Apabila obyek hibah tersebut telah dibalik nama atau telah disertifikatkan atas nama penerima hibah, maka sertifikat dinyatakan tidak berlaku lagi. Pemberi hibah dapat mengajukan permohonan kepada Kantor Pertanahan kembali dengan adanya pembatalan hibah tersebut dan sertifikat dapat dikembalikan lagi atas nama pemberi hibah atau ahli waris.

Dalam pembatalan akta hibah oleh ahli waris setelah putusan Pengadilan Agama pada dasarnya, dalam Agama Islam hibah dapat ditarik kembali sebagaimana yang telah tercantum dalam Pasal 212 KHI bahwa hibah tidak dapat ditarik kembali, kecuali hibah orang tua kepada anaknya. Menurut Pasal 210 KHI, yaitu pemberi hibah dapat menghibahkan sebanyak-banyak $1 / 3$ harta bendanya kepada orang lain atau lembaga dihadapan dua orang saksi. Menurut KHI bahwa hibah dalam perkara ini tidak sah dan dapat dilakukan penarikan atau pencabutan kembali. Karena tidak terpenuhinya salah satu persyaratan dalam syarat-syarat pemberian hibah menurut hukum Islam.

\section{DAFTAR PUSTAKA}

Abdul Manan, 2006, Aneka Masalah Hukum Perdata Islam Di Indonesia, Jakarta: Kencana.

Abdurrahman, 1992, Kompilasi Hukum Islam di Indonesia, Jakarta: Akademika Presindo.

${ }^{15}$ Ahmad Azhar Basyir, Op.Cit., hlm. 125 
Abdul Wahid, Sunardi, Mariyadi, 2017, Penegakan Kode Etik Profesi Notaris, Jakarta: Nirmana Media.

Ahmad Azhar Basyir, 2004, Hukum Waris Islam, Yogyakarta: UII Press.

Herlien Budiono, 2012, Kumpulan Tulisan Hukum Perdata di Bidang Kenotariatan, Bandung: Citra Aditya Bakti.

Moh. Muhibbin dan Abdul Wahid, 2017, Hukum Kewarisan Islam, Jakarta: Sinar Grafika.

MR Martiman Prodjihanimidjojo, 2012, Hukum Perkawinan Indonesia, Jakarta: Indonesia Legal Center Publishing.

R. Soeroso, 1994, Praktik Hukum Acara Perdata Tata Cara dan Proses Persidangan, Jakarta: Sinar Grafika.

Sudarsono, 1991, Hukum Waris dan Sistem Bilateral, Jakarta: Rineka Cipta.

Suratman, dan Philips Dillah, 2015,Metode Penelitain Hukum,Bandung: Alfabeta.

Widya Anggaraeni, 2006, Tangung Gugat Pemberi Hibah Akibat Pembatalan Hibah, Surabaya: Universitas Airlangga. 